\title{
Powerline bioactivity - more than magnetism
}

\author{
G Hugh Sidaway
}

\begin{abstract}
Background: Previous work on the possible public health impact of electricity utilization has mostly considered low frequency electromagnetic fields, particularly those associated with high voltage overhead powerlines, but no generally accepted biological mechanism has been proposed. The present study seeks to expand the area of debate to include airborne electroactivity.

Findings: From a literature survey it is concluded that there is statistically significant published evidence consistent with the involvement of airborne electroactive agents in the powerline proximity modulation of some cytokine activity. Attention is drawn to overhead line fault associated corona discharge action as a source of potentially bioactive agents deserving careful study in view of the widespread close residential proximity to overhead power distribution lines in many countries. Particular attention is given to the role of electricity access associated faults as a possible explanation for the high childhood leukaemia rates in certain districts of Mexico City.

Conclusions: Despite more than 30 years research worldwide there is no generally accepted biological mechanism to explain the adverse health impact of overhead powerline residential proximity. Expanding the area of consideration to include airborne electroactivity may provide the basis for a plausible outline model of such a mechanism. More attention should be given to this research area.
\end{abstract}

Keywords: Childhood leukaemia; Overhead powerlines; Air ionization; Superoxide; Magnetic fields; Immune dysfunction; Epigenetics; Mexico

\section{Findings}

\section{Powerlines}

The public health impact of electricity utilization has been a matter of controversy for over 30 years. At the present time, general awareness of this issue may be enhanced by recent publication of the results of the French Geocap study (Sermage-Faure et al. 2013). These authors conclude that their findings support the hypothesis that close residential proximity to a very high voltage overhead line may be associated with an increased incidence of childhood acute leukaemia. Most studies have concerned the electromagnetic field (EMF) aspect- for example, the work of Li et al. (2011) which established a link between childhood asthma and maternal exposure to low-frequency EMFs. These however constitute only one component of the electricity utilization environment. Concentration on electromagnetic fields has diverted attention from the ability of many electrically energized structures to generate air ions by 'arcing' even at low voltages :for example the sparking of electromechanical

Correspondence: derlwyn8@ntlworld.com

111 Waun Fach Pentwyn, Cardiff CF23 7BD, UK relays in older telephone exchanges operating at less than $100 \mathrm{~V}$ (see literature cited in reference 5 (page 307) of Sidaway (2012).

Extending epidemiological considerations to include lower-voltage overhead powerlines, rather than the high magnetic field producing, high voltage lines presently considered would lead to conclusions contrasting sharply with those expressed by Schmeidel and Blettner (Schmiedel and Blettner 2010) that "the public health impact is low". The "Kaiser Permanente Medical Care Program" (KP) population in California studied in the report by Li et al. (2011) was originally defined by $\mathrm{Li}$ et al. (2002) who noted that maximum magnetic field exposure levels were comparable with those found in a nationwide survey (Zaffanella and Kalton 1998) which associated high magnetic field exposure at home with close residential proximity to overhead powerlines (page 6-9, and see page A-56). The purpose of this "1000 Person Survey" was to establish the magnetic field exposure of the general U.S. population by measurements on a population sample, selected by random digit telephone number dialling such that each household selected was considered to represent 23,350 other households

\section{实}

(C) 2013 Sidaway; licensee Springer. This is an Open Access article distributed under the terms of the Creative Commons Attribution License (http://creativecommons.org/licenses/by/2.0), which permits unrestricted use, distribution, and reproduction in any medium, provided the original work is properly cited. 
not contacted. Although the authors advise that the survey findings should be interpreted with caution, data presented on page 5-51 appear to suggest that around $75 \%$ of the U.S. population may live less than $50 \mathrm{~m}$ from some form of overhead powerline. The population of the KP study was drawn from an area similar to, and to some extent overlapping with, that covered by the "Northern California Childhood Leukaemia Study" (NCCLS), for example Chang et al. (2009) who found a positive association between childhood leukaemia and maternal immunoglobin status. Web-accesible streetviews (web link Ref 1) suggest a broad similarity with power distribution wiring near apartments in Denver, Colorado shown in a photograph published by Crumpton (2000) to illustrate the type of overhead wiring studied in the pioneering work by Wertheimer and Leeper (1979). Some characteristics of the overhead distribution lines widely used in the U.S. are discussed in literature cited in Sidaway (2012). As evidenced by streetviews (web link Ref 1 ), similar distribution wiring is widely used in countries such as Australia, China, Japan, Mexico and New Zealand.

\section{Immune dysfunction}

A long-term study of possible high voltage transmission line effects on sheep was initiated in 1990 by Bonneville Power Administration, Portland, Oregon. Results of the study were presented in a series of Reports, the last two of which were published by the Electric Power Research Institute, which sponsored Phases 4 and 5 of the study. Experimental animals were housed in a pen within a powerline corridor containing $3 \times 500 \mathrm{kV}$ and $2 \times 230 \mathrm{kV}$ transmission lines. Control animals were some $230 \mathrm{~m}$ distant. Phases 2 and 3 of the study found that activity of the cytokine IL-1 was significantly reduced in experimental animals but removing the animals from exposure conditions resulted in a return of cytokine activity to control levels (see Sidaway 2012). The Phase 2 Report (Stormshak 1993) contains (otherwise unavailable) information regarding possible immune dysfunction associated with the development of fungal skin infections in sheep exposed to the powerline environment. Two human infections also occurred in study personnel. These observations are clearly important as Chang et al. (2011) noted that childhood acute lymphoblastic leukaemia may be associated with a dysregulated immunefunction. Il1 has an important role in regulating defence mechanisms against pathogens including fungi (Ben-Sasson et al. 2009; Sims and Smith 2010). During Phases 4 and 5, a second experimental pen was added in which animals were shielded from the powerline electric field by grounded metal screens (see Sidaway 2012). A summary of parts of Reports 4 and 5 was published by Hefeneider et al, (Hefeneider et al. 2001) who noted a significant correlation between wind direction and IL-1 activity. This would be consistent with the action of powerline-associated airborne bioactive agents.
Respiratory airway epithelial cells are positioned to monitor the ambient atmospheric environment and detect and respond to airborne potential pathogens via pathogen structure pattern recognition receptors (Kato and Schleimer 2007). It is possible that epithelial cell function could be modulated by airborne electric charge carrying agents, leading to changes in cytokine activity. It is one purpose of the present communication to suggest that such agents could act as environmental cues in the context of the "developmental origin of health and disease" model of human developmental plasticity (Hochberg et al 2011) and could thus be relevant to the suggested association between childhood asthma and maternal magnetic field exposure ( $\mathrm{Li}$ et al. 2011). The same (or related) electro-environmental cues could drive the association between electricity utilization and some childhood cancers - note Chang et al. (2011) from the NCCLS area. As pointed out by Sidaway (2012), unlike EMFs, air ions occur naturally, and cover such a broad structural spectrum as to make it difficult to specify, with certainty, the precise nature and origin of putative causative agents. By clouding the issue of adverse health impact hazard attribution, the model presented here should reduce the risk of a confrontational approach to public health concerns. An apparent association between health impacts and air ionization, whether derived from high voltage corona activity or more general fault-associated electrical arcing, could justify the exploration and perhaps introduction of a range of precautionary mitigation/prevention measures. The costs of any such measures need to be offset against present and predicted healthcare economic burdens. In purely economic terms, a possible reduction in adverse public health impacts should justify consideration of financial resource redistribution via subsidies.

\section{Environmental epigenetics}

Goldstein et al. (1992) found that the biological activity of negative air ions involves the superoxide anion-radical, and suggest a "prominent ecological and evolutionary" role for exogenous superoxide. In this context note that Esteller (2007) proposed that hypermethylation of tumour suppressor genes may be related to the level of exposure to external carcinogen agents. Biologically important reactions of the superoxide radical are discussed by Maynard et al. (2009) who note that DNA bases, particularly guanine, are sensitive to damage by reactive oxygen species. Valinluck et al. (2004) consider the role of guanine oxidation in epigenetic signal propagation, while Turrens (2003) discusses the endogenous production of superoxide anion and notes the importance of this radical as a precursor of other reactive oxygen species, particularly hydroxyl radical. The potential consequences of electric charge-carrying agent inhalation need to be carefully considered in the context of hydrogen peroxide formation and diffusion (Goldstein et al. 1992; Maynard et al. 2009). Note also the reported association 
(Yang et al. 2008) between the residential powerline environment and polymorphisms of the DNA repair gene XRCC1.

\section{Mexico}

Perez-Saldivar et al (2011) note that the frequency of childhood acute Lymphoblastic leukaemia in Mexico City is among the highest in the world. These authors also note that the standardized average annual incidence rate for childhood leukaemia was highest in the "relatively affluent" Mexico City borough of Cuauhtemoc. It should be noted that, according to To web link Ref 2, "Street vendors have proliferated in Cuauhtemoc". This is important as illegal electricity access by street vendors is widespread in Mexico City (see literature cited in Sidaway (2012) and could thus increase the frequency of potentially faulty overhead powerline connections in Cuauhtemoc and perhaps some other areas. See also Additional files 1 and 2, and consider the findings of Yang et al. (2008) regarding a possible association between the residential powerline environment and polymorphisms of the DNA repair gene XRCC1.

\section{Additional files}

\section{Additional file 1: Bioactivity of Electricity Utilization - Broadening} the Debate Part 1 - Epidemiology.

Additional file 2: Bioactivity of Electricity Utilization - Broadening the Debate Part 2 - Biology.

\section{Abbreviations}

EMF: Electromagnetic field; KP: Kaiser Permanente Medical Care Program; NCCLS: Northern California childhood leukemia study.

\section{Competing interests}

The author declares that he has no competing interests.

\section{Acknowledgements}

As previously, I thank my wife Heather and our children Hugh and Kerry for their unfailing support without which this work would not have been possible.

Received: 10 May 2013 Accepted: 29 July 2013

Published: 11 September 2013

\section{References}

Ben-Sasson SZ, Hu-Li J, Quiel J, Cauchetaux S, Ratner M, Shapira I, Dinarello CA, Pau WE (2009) IL-1 acts directly on CD4 T cells to enhance their antigen-driven expansion and differentiation. Proc Natl Acad Sci U S A 106:7119-7124

Chang JS, Buffler PA, Metayer C, Chokkalingam AP, Patoka J, Kronish D, Wiemels $J$ (2009) Maternal immunoglobin E and childhood leukemia. Cancer Epidemiol Biomarkers Prev 18:2221-2227

Chang JS, Zhou M, Buffler PA, Chokkalingam AP, Metayer C, Wiemels JL (2011) Profound deficit of IL-10 at birth in children who develop childhood acute lymphoblastic leukemia. Cancer Epidemiol Biomarkers Prev 20:1736-1740

Crumpton M (2000) Dissecting the pylon problem. Science and Public Affairs 2000(August):24-26

Esteller M (2007) Epigenetic gene silencing in cancer the DNA hypermethylome. Hum Mol Genet 16(review issue 1):R50-R59

Goldstein NI, Goldstein RN, Merzlyak MN (1992) Negative air ions as a source of superoxide. Int J Biometeorol 36:118-122
Hefeneider SH, McCoy SL, Hausman FA, Christensen HL, Takahashi D, Perrin N, Bracken TD, Shin KY, Hall AS (2001) Long-term effects of 60-Hz electric vs. magnetic fields on IL-1 and IL-2 activity in sheep. Bioelectromagnetics 22:170-177

Hochberg Z, Feil R, Constancia M, Fraga M, Junien C, Carel J-C, Boileau P, Le Bouc Y, Deal CL, Lillycrop K, Scharfmann R, Sheppard A, Skinner M, Szyf M, Waterland RA, Waxman DJ, Whitelaw E, Ong K, Albertsson-Wikland K (2011) Child health, developmental plasticity, and epigenetic programming. Endocr Rev 32:159-224

Kato A, Schleimer RP (2007) Beyond inflammation airway epithelial cells are at the interface of innate and adaptive immunity. Curr Opin Immunol 19:711-720

Li D-K, Odouli R, Wi S, Janevic T, Golditch I, Bracken TD, Senior R, Rankin R, Iriye R (2002) A population-based cohort study of personal exposure to magnetic fields during pregnancy and the risk of miscarriage. Epidemiology 13:9-20

Li D-K, Chen H, Odouli R (2011) Maternal exposure to magnetic fields during pregnancy in relation to the risk of asthma in offspring. Arch Pediatr Adolesc Med 165:945-950

Maynard S, Schurman SH, Harboe C, de Siuza-Pinto NC, Bohr VA (2009) Base excision repair of oxidative DNA damage and association with cancer and aging. Carcinogenesis 30:2-10

Perez-Saldivar ML, Fajardo-Gutierrez A, Bernaldez-Rios R, Martinez-Avalos A, Medina-Sanson A, Espinoza-Hernandez L, JD F -C, Amador-Sanchez R, Penaloza-Gonzalez JG, Alvarez-Rodriguez FJ, Bolea-Murga V, Flores-Lujano J, Rodriguez-Zepeda MC, Rivera-Luna R, Dorantes-Acosta EM, JimenezHernandez E, Alvarado-Ibarra M, Velazquez-Avina MM, Torres-Nava JR, Duarte-Rodriguez DA, Paredes-Aguilera R, Campo-Martinez MA, CardenasCardos R, PH A -G, Bekker-Mendez VC, Ortega-Alvarez MC, Mejia-Arangure JM (2011) Childhood acute leukemias are frequent in Mexico City: descriptive epidemiology. BMC Cancer 11:355. doi:10.1186/1471-2407-11-355

Schmiedel S, Blettner M (2010) The association between extremely low-frequency electromagnetic fields and childhood leukaemia in epidemiology enough is enough? Br J Cancer 103:931-932

Sermage-Faure C, Demoury C, Rudant J, Goujon-Bellec S, Guyot-Gobin A, Deschamps F, Hemon D, Clavel J (2013) Childhood leukaemia close to highvoltage power lines - the Geocap study, 2002-2007. Br J Cancer. doi:10.1038/ bjc.2013.128

Sidaway GH (2012) Bioactivity of electricity utilization-broadening the debate. Paper presented at the Childhood Cancer 2012 conference. Church House, Westminster, London, 24-26 April 2012 an access link for this paper is provided at https://reflect.ifl.ac.uk/webfolio.aspx?webfolioid=4097098

Sims JE, Smith DE (2010) The IL-1 family regulators of immunity. Nat Rev Immunol 10:89-102. doi:10.1038/nri2691

Stormshak F (1993) Joint HVAC transmission EMF environmental study, final report on experiment 2. Bonneville Power Administration, Portland, OR

Turrens JE (2003) Mitochondrial formation of reactive oxygen species. J Physiol 552:335-344

Valinluck V, Tsai H-H, Rogstad DK, Burdzy A, Bird A, Sowers LC (2004) Oxidative damage to methyl-CpG sequences inhibits the binding of the methyl CpG binding domain (MBD) of methyl $\mathrm{CpG}$ binding protein 2 (MeCP2). Nucleic Acids Res 32:4100-4108

Web link ref 1: Earth-scout.com - search engine for Street View, Google Maps and Google Earth. http://www.earth-scout.com/Streetview - Accessed 23 April 2013

Web link ref 2: Wikipedia: Colonia Cuauhtemoc, Mexico City. http://en.wikipedia. org/wiki/Colonia_Cuauht\%C3\%A9moc,_Mexico_City Accessed 23 April 2013

Wertheimer N, Leeper E (1979) Electrical wiring configurations and childhood cancer. Am J Epidemiol 109:273-284

Yang Y, Jin X, Yan C, Tian YTang J, Shen X (2008) Case only study of interactions between DNA repair genes ( $h M L H 1$, APEX1, MGMT, XRCC1 and XPD) and lowfrequency electromagnetic fields in childhood acute leukemia. Leukemia and Lymphoma 49:2344-2350

Zaffanella LE, Kalton GW (1998) Survey of personal magnetic field exposure, Phase II: 1000 person survey. EMF RAPID program engineering project No. 6 Enertech Consultants, (http://www.emf-data.org/rapid6-report.html) Accessed 25 April 2013

doi:10.1186/2193-1801-2-454

Cite this article as: Sidaway: Powerline bioactivity - more than magnetism. SpringerPlus 2013 2:454 